\title{
Molecular Diversity of Methicillin-Resistant and -Susceptible Staphylococcus aureus Detected in Animals: A Focus on Aquatic Animals
}

\author{
Vanessa Silva ${ }^{1,2,3,4,5} \mathbb{1 D}_{\text {, Andreia Monteiro }}{ }^{1}$, Maria Porto ${ }^{1}$, Ana Sampaio ${ }^{6,7}$, Luís Maltez ${ }^{1,5}$, \\ José Eduardo Pereira ${ }^{1,5}$, Florin Aonofriesei ${ }^{8}$, José Luis Capelo ${ }^{9,10}\left(\mathbb{D}\right.$, Gilberto Igrejas ${ }^{2,3,4}$ (D) \\ and Patrícia Poeta $1,4,5, * \mathbb{D}$
}

Citation: Silva, V.; Monteiro, A.; Porto, M.; Sampaio, A.; Maltez, L.; Pereira, J.E.; Aonofriesei, F.; Capelo, J.L.; Igrejas, G.; Poeta, P. Molecular Diversity of Methicillin-Resistant and -Susceptible Staphylococcus aureus Detected in Animals: A Focus on Aquatic Animals. Diversity 2021, 13, 417. https://doi.org/10.3390/ d13090417

Academic Editors: Michael Wink and Ipek Kurtboke

Received: 28 July 2021

Accepted: 23 August 2021

Published: 30 August 2021

Publisher's Note: MDPI stays neutral with regard to jurisdictional claims in published maps and institutional affiliations.

Copyright: (C) 2021 by the authors Licensee MDPI, Basel, Switzerland. This article is an open access article distributed under the terms and conditions of the Creative Commons Attribution (CC BY) license (https:// creativecommons.org/licenses/by/ $4.0 /)$.
1 Microbiology and Antibiotic Resistance Team (MicroART), Department of Veterinary Sciences, University of Trás-os-Montes and Alto Douro (UTAD), 5000-801 Vila Real, Portugal; vanessasilva@utad.pt (V.S.); andreiamonteiro9977@gmail.com (A.M.); gondiniz35@gmail.com (M.P.); lmaltez@utad.pt (L.M.); jeduardo@utad.pt (J.E.P.)

2 Department of Genetics and Biotechnology, University of Trás-os-Montes and Alto Douro (UTAD), 5000-801 Vila Real, Portugal; gigrejas@utad.pt

3 Functional Genomics and Proteomics Unit, University of Trás-os-Montes and Alto Douro (UTAD), 5000-801 Vila Real, Portugal

4 LAQV-REQUIMTE, Department of Chemistry, NOVA School of Science and Technology, Universidade Nova de Lisboa, 2829-516 Caparica, Portugal

5 Veterinary and Animal Research Centre, Associate Laboratory for Animal and Veterinary Science (AL4AnimalS), University of Trás-os-Montes and Alto Douro (UTAD), 5000-801 Vila Real, Portugal

6 Department of Biology and Environment, University of Trás-os-Montes and Alto Douro (UTAD), 5000-801 Vila Real, Portugal; asampaio@utad.pt

7 Centre for the Research and Technology of Agro-Environmental and Biological Sciences (CITAB), University of Trás-os-Montes and Alto Douro (UTAD), 5000-801 Vila Real, Portugal

8 Faculty of Natural Sciences and Agricultural Sciences, Department of Biology-Ecology, Ovidius University of Constanta, University Street, 900470 Constanta, Romania; aonofriesei_florin@yahoo.fr 9 BIOSCOPE Group, LAQV@REQUIMTE, Chemistry Department, Faculty of Science and Technology, NOVA University of Lisbon, 2825-466 Almada, Portugal; jlcm@fct.unl.pt

10 Proteomass Scientific Society, 2825-466 Costa de Caparica, Portugal

* Correspondence: ppoeta@utad.pt; Tel.: +351-259350466

\begin{abstract}
Staphylococcus aureus (S. aureus) are one of the best-known opportunistic pathogens capable of causing different types of infections in animals. Furthermore, it has the ability to acquire resistance to various antibiotics very easily. Methicillin-resistant S. aureus (MRSA) are currently of great concern as they are the leading cause of infections in humans and animals, with a major impact on health and the economy. Several studies already demonstrate that the spread of MRSA is constantly increasing due to its ability to form reservoirs in humans, animals and the environment. In fact, several works have already identified the presence of these bacteria in animals, including domestic animals, farm animals and even wild animals. Furthermore, the incidence of various $S$. aureus strains in aquatic animals has also been reported by different authors, although it is still a rarely discussed topic. Some of these strains have previously been associated with humans and other animals. Strain 398 is the strain that manages to infect a wider spectrum of hosts, having been identified in several different species. Aside from this strain, many others have yet to be identified. In addition, many of these strains have virulence factors and antibiotic resistance genes that worsen the situation. The present work is a review of studies that intend to investigate the epidemiology of this agent in samples of aquatic animals from different origins, in order to better understand its distribution, prevalence and the molecular lineages associated with these species.
\end{abstract}

Keywords: S. aureus; MRSA; wildlife; aquatic animals 


\section{Introduction}

The rapid emergence of multiresistant bacteria is one of the greatest threats to public health worldwide. According to the European Center for Disease Prevention and Control, in Europe alone, antibiotic resistance has an economic impact of around EUR 1.5 billion and is estimated to be responsible for approximately 33,000 deaths each year [1]. This problematic situation is, in large part, related to the incorrect prescription of these drugs, their overuse, and the lack of development of new drugs due to the low economic investment in the pharmaceutical industries [2]. Epidemiological studies have already shown that there is a direct relationship between the overuse of antibiotics and the emergence of resistant bacterial strains. However, despite warnings about the consequences of their overuse, these drugs continue to be highly prescribed worldwide [3], especially penicillins, which currently account for $85 \%$ of beta-lactams used [4]. The penicillinase enzyme was first detected in Staphylococcus aureus (S. aureus) shortly after penicillin began to be used, which shows that the consumption of an antibiotic will eventually favor the selection of resistant strains [5]. Furthermore, in some countries, antibiotics can be easily purchased without the need for a medical prescription and at a low cost, which can cause their consumption to be uncontrolled [6]. The incorrect prescription of antibiotics in the hospital sector also contributes to the emergence of resistance. According to some studies, the choice of antibiotic, as well as the duration of treatment, is incorrect in $30-50 \%$ of cases [7]. The incorrect prescription of these drugs has questionable therapeutic benefits and can bring potential complications for the patient [8]. The use of these drugs in the agricultural sector has also been identified as a risk factor for the emergence of resistance and has received special attention in recent years. Although the administration of antibiotics in farm animals has already been banned in Europe, in many countries, antibiotics continue to be used indiscriminately to promote the growth of these animals [9]. The indiscriminate use of antibiotics, whether in human or veterinary medicine, creates a natural selective pressure in which resistant bacteria survive and reproduce, even in the presence of the antibiotic [10]. When used in sub-inhibitory concentrations, an antibiotic is able to promote genetic alterations, such as alterations in gene expression, horizontal gene transfer and mutagenesis [11]. Antibiotic-induced changes in gene expression can increase the virulence of the bacterial strain in question, while mutagenesis and horizontal gene transfer processes promote antibiotic resistance and its spread, respectively [11]. Although this issue has emerged in clinical practice, antimicrobial resistance is found in several other sectors such as animal production facilities, agriculture, effluents and water systems, making it a problem that involves not only humans and animals, but also the entire environment [12-16]. In addition, the microorganisms found in the environment converge with human and animal pathogens, and there may be exchanges and transfers of resistance genes between different bacterial strains, which further aggravates this problem [5]. Due to this situation, it has already been estimated that most antibiotics currently used to fight bacterial infections will become completely useless within five to ten years, taking us back to the pre-antibiotic era [10].

\section{Staphylococcus spp.}

The Staphylococcus genus belongs to the Staphylococcaceae family and features coccishaped microorganisms that are capable of causing various infections. This family includes more than 45 species and 24 subspecies, presenting typically respiratory and fermentative metabolisms, most of them aerobic or facultative anaerobic [17]. These bacteria were first described by surgeon Sir Alexander Ogston in the 1980s and their name comes from the Greek staphylos (grape) and kokkos (berry). They are typically characterized as being Gram-positive and catalase-positive, although some strains have been identified as catalasenegative. Furthermore, these bacteria are capable of producing a huge variety of virulence factors responsible for their level of pathogenicity [18].

S. aureus are one of the species of the Staphylococcaceae family, classified as coagulasepositive (SCoP), oxidase-negative and salt-tolerant (they are able to grow in a medium 
containing $10 \% \mathrm{NaCl}$ ) [17]. These bacteria are generally commensal residents of the human flora, residing in the skin and mucosa of about $30 \%$ of individuals. However, commensal staphylococci are recognized as opportunistic pathogens capable of causing a wide variety of infections [19]. In the case of $S$. aureus these infections can range from skin and soft tissue infections to more severe infections such as necrotic pneumonia, endocarditis and osteomyelitis [20]. This bacterium has the ability to infect almost every organ system in the human body, often with fatal consequences. This remarkable adaptability is largely due to the wide range of virulence factors they produce, many of which are encoded in plasmids, transposons, prophages, and pathogenicity islands [5]. The acquisition of resistance genes to a variety of antibiotics has made $S$. aureus one of the most important pathogens today. Methicillin-resistant $S$. aureus (MRSA) are currently a serious problem in hospitals around the world. These bacteria are estimated to be responsible for around 171,200 infections in Europe each year [21]. These bacteria were first described in 1961 in England, shortly after methicillin was introduced into clinical practice [22]. However, the genome sequencing of some isolates suggests that these bacteria may have emerged in the 1940s, due to the excessive use of penicillin [22]. In fact, just 2 years after the introduction of penicillin, around $80 \%$ of $S$. aureus isolates were resistant to this antibiotic [23]. Methicillin resistance occurred through two distinct mechanisms: firstly, by producing enzymes that hydrolyze and destroy beta lactams, called beta lactamases, which were encoded by the blaZ gene [24]; then, by producing a modified penicillin binding protein (PBP2a) that participated in the synthesis of peptidoglycan, a natural component of the bacterial cell wall. However, this modified protein had an inaccessible active site, preventing antibiotic binding and thus, cell wall synthesis was not affected, allowing the bacteria to survive [23]. The PBP2a protein was encoded by the mec genes $(m e c \mathrm{~A} / \mathrm{mecC})$. These genes were embedded within the staphylococcal mec cassette (SCCmec), a highly transmissible mobile genetic element between bacteria, which could be classified into at least 14 different types (I-XIV) [25].

Initially, MRSA was restricted only to the hospital environment, causing different types of nosocomial infections and, for this reason, they were called HA-MRSA (Hospitalacquired MRSA) [26]. Years later, MRSA began to be identified in individuals with no prior contact with the hospital environment and thus came to be called CA-MRSA (Communityacquired MRSA) [27]. More recently, a third type of MRSA strain associated with farm animals (LA-MRSA) has been reported. Genotypically CA-MRSA strains were newer and more virulent and usually contained SCCmec type IV or V [26]. Despite being susceptible to non-beta lactam antibiotics, these strains generally carried the gene for PantonValentine leukocidin, a protein associated with greater virulence [28]. On the contrary, HA-MRSA strains were associated with SCCmec types I, II, and III, and were resistant to non-beta lactam antibiotics, especially aminoglycosides, macrolides, lincosamides and fluoroquinolones [26].

CA-MRSA strains have been extensively studied in recent years and have been reported in several animals including domestic pets, cattle, pigs and horses, as well as in wild animals. Conversely, MRSA strains associated with farm animals (LA-MRSA) have emerged in the human population, which highlights the idea that there is a traffic of these microorganisms between different species.

\section{MRSA in Animals}

The first reported case of MRSA infection in animals was the case of a bovine mastitis that occurred in Belgium in the early 1970s. After this case many others followed in both companion and farm animals. Molecular typing studies demonstrated that some MRSA strains have host specificity, while others were capable of colonizing or infecting a wide variety of animals [29]. Typing studies were of high clinical and epidemiological importance as they allowed for the determination of causes of infection, modes of transmission and relationships with other bacteria, as well as accessing the specific characteristics of a particular genetic lineage [5]. Thus, MRSA were generally characterized by Multilocus 
Sequence Typing (MLST), spa-typing or SCCmec typing. Table 1 describes the main MRSA genetic lines associated with companion and farm animals.

Table 1. Major MRSA strains associated with companion animals and farm animals.

\begin{tabular}{lll}
\hline & ST & spa-Types \\
\hline Companion animals & ST5, ST22, ST398 & $\mathrm{t} 032, \mathrm{t} 432, \mathrm{t} 747, \mathrm{t} 4726$ \\
Horses & ST1, ST8, ST22, ST254, ST398 & $\mathrm{t} 11, \mathrm{t} 036, \mathrm{t} 127$ \\
Pigs & ST1, ST9, ST97. ST398 & $\mathrm{t} 011$ \\
Cattle & ST8, ST130, ST398 & $\mathrm{t} 011, \mathrm{t} 034$ \\
Birds & ST5, ST398 & $\mathrm{t} 011, \mathrm{t} 567$ \\
\hline
\end{tabular}

ST: sequence type.

In farm animals, the first case of MRSA colonization was reported in 2005 in the Netherlands [30]. This new MRSA clone with ST398 was identified in pigs and clustered within the clonal complex (CC) 398 [9]. In another European study that analyzed the presence of MRSA associated with pigs, it was found that the most frequent strain was ST398, but other strains such as ST1, ST9 and ST97 were also reported [31]. In fact, it is scientifically well-known that the CC398 strain asymptomatically colonizes about half of these animals in swine farms. Although ST398 is mostly associated with swine, this lineage has also been reported in other farm animals $[32,33]$. This strain has a broad host spectrum and is commonly found in $77-86 \%$ of people with occupational activities who have direct contact with pigs, causing the same type of infections in humans as other strains of S. aureus or MRSA in general [34]. Additionally, the strain CC130 appears to have a low host specificity. In a very large study by Monecke et al., 2016, this strain was identified in a huge variety of animals such as the rat, hedgehog, red fox, common hare and deer [35]. Some MRSA strains appear to be specific to bovines, namely CC130, ST425 and CC1943 [29]. In fact, S. aureus is currently the leading cause of infection in cows, with a huge economic impact on the dairy industry [29]. A study by Tenhagen et al. concluded that most MRSA isolates obtained from these animals, regardless of their origin, belonged to the types $\mathrm{t} 011$ and $\mathrm{t} 034$, both associated with the CC398 clonal complex [36].

Regarding birds, the CC5 clonal complex seems to be the predominant complex, being widely distributed in several continents [37]. In the study by Monecke et al. this clonal complex was identified in gray partridge [35]. Although CC5 seems predominant, CC398 isolates associated with chickens and turkeys with spa types t011 and t567 have been identified in Europe [38].

In the case of companion animals such as dogs and cats, a correlation between the clonal types found in these animals and the clonal types that infect humans in the same geographic region has already been verified [29]. Apparently, contact between pets and their owners favors the transmission of these bacteria. Therefore, the clonal types most frequently found in companion animals correspond to the clonal types dominant at that location. For example, in the UK, MRSA isolates from dogs correspond to the dominant HA-MRSA strain at that site, ST22 [39]. The same results are obtained in Portugal, where four different spa types were identified (t032, $\mathrm{t} 432, \mathrm{t} 747$ and $\mathrm{t} 4726)$, with $\mathrm{t} 032$ being the most frequent [40].

In horses, the most frequently found MRSA strains are, as with companion animals, strains associated with humans. The strain, CC8 (ST8 and ST254), is associated with the most cases of colonization and infection in horses in Canada, while in Europe the most frequently reported strains are ST1, ST22, ST254 [41]. In the same study, the spa types reported were $\mathrm{t} 036, \mathrm{t} 011$ and $\mathrm{t} 127$, with $\mathrm{t} 036$ being the most frequent.

Regarding wild animals, a study by Porrero et al., 2014, analyzed the genetic diversity and predominant genotypes in different animal species in Spain [42]. Samples were collected from the skin and nostrils of animals and the isolates were characterized by spa-typing and MLST. Sixty-three different spa-types were identified, of which the most common was $\mathrm{t} 528$ (Iberian ibex), followed by $\mathrm{t} 548$ and $\mathrm{t} 11212$ (red deer) and $\mathrm{t} 3750$ (wild boar). Regarding the sequence types (ST), through the MLST technique, it was possible 
to identify 27 different STs. The most frequent STs were ST581 (Iberian ibex), ST425 (red deer) and ST2328 (wild boar). More recently, the presence of an CC398-MRSA isolate was identified with a new variant, SCCmec type IV J3, in wild boar [43]. Monecke et al. analyzed fecal samples from 2,855 wild animals. In total, $155 \mathrm{~S}$. aureus were isolated, of which 124 were further genetically characterized. From a genetic point of view, 29 different clonal complexes (CC) were identified as associated with different animal species, namely: CC1, CC5, CC6, CC7, CC8, CC9, CC12, CC15, CC22, CC25, CC30, CC49, CC59, CC88, CC97, CC130, CC398, CC599, CC692, CC707, CC1956, and CC2767 [35].

Silva et al. have also identified the presence of MRSA in wild rodent samples. In this study, six MRSA were identified, three of which contained the mecC gene, while the other three contained the mecA gene [44]. All mecC-MRSA isolates belonged to ST1945 (which belonged to CC130) and spa-type t1535, while mecA-MRSA isolates belonged to ST22 and ST36 with spa-types t747 and t018. Furthermore, this was the first study to report MRSA mecC in Portugal. Different results were obtained by Mrochen et al. who obtained MRSA isolates from different strains, the most common being CC49, followed by CC1946 and ST890 [45]. In this work, similarly to the previous one, one mecC-MRSA isolate was also identified, showing that rodents function as reservoirs or vectors of S. aureus.

\section{MRSA in Aquatic Animals}

In general, it is possible to verify that there is a huge genetic variety of $S$. aureus associated with different animal species in several continents. Wildlife can serve as a reservoir for S. aureus, and later on there may be a transmission to domestic animals, farm animals and, directly or indirectly, to humans. These natural S. aureus reservoirs contribute to the exchange of resistance and virulence genes between bacteria, enhancing the appearance of new strains [46]. Table 2 shows the genetic diversity of MRSA and methicillin-susceptible $S$. aureus strains (MSSA) strains isolated from aquatic animals.

Table 2. Animal species: location of isolation and genetic lineages of MSSA and MRSA isolated from aquatic animals.

\begin{tabular}{|c|c|c|c|c|c|c|}
\hline \multirow{2}{*}{ Animal Species } & \multirow{2}{*}{ Location } & \multirow{2}{*}{$\begin{array}{c}\text { MRSA/MSSA } \\
\text { (Number of } \\
\text { Isolates) }\end{array}$} & \multicolumn{2}{|c|}{ Clonal Lineages } & \multirow{2}{*}{ Virulence } & \multirow{2}{*}{ Reference } \\
\hline & & & spa-Type & ST/CC & & \\
\hline $\begin{array}{c}\text { Canada geese (Branta } \\
\text { canadensis) }\end{array}$ & $\begin{array}{l}\text { Northeast } \\
\text { Ohio, USA }\end{array}$ & $\begin{array}{l}\text { MRSA (7) } \\
\text { MSSA (6) }\end{array}$ & $\begin{array}{c}\mathbf{t 0 0 8 ,} \mathbf{t 2 5 9 5}, \\
\mathbf{t 1 2 7 ,} \text { t1149, t002, } \\
\text { t008, t1451, } \\
\text { t15031, t688 }\end{array}$ & $\begin{array}{c}\text { ST8, ST291, } \\
\text { ST5, ST8, ST398, } \\
\text { ST211 }\end{array}$ & $\begin{array}{l}\text { PVL+, } \\
\text { PVL-, } \\
\text { PVL- }\end{array}$ & [47] \\
\hline $\begin{array}{c}\text { Green mussels } \\
\text { (Perna canaliculus) }\end{array}$ & \multirow{2}{*}{ Malasya } & MRSA (4) & \multirow[b]{2}{*}{ n.d. } & \multirow[b]{2}{*}{ n.d. } & \multirow[b]{2}{*}{ n.d. } & \multirow[b]{2}{*}{ [48] } \\
\hline $\begin{array}{c}\text { Blood cockles } \\
\text { (Anadara granosa) }\end{array}$ & & MRSA (3) & & & & \\
\hline $\begin{array}{l}\text { Risso's dolphin } \\
\text { (Grampus griseus) }\end{array}$ & \multirow{2}{*}{ Italy } & \multirow{2}{*}{ MRSA (2) } & \multirow{2}{*}{ t008 } & \multirow{2}{*}{ ST8 } & \multirow{2}{*}{ n.d. } & \multirow{2}{*}{ [49] } \\
\hline $\begin{array}{l}\text { Bottlenose dolphin } \\
\text { (Tursiops truncatus) }\end{array}$ & & & & & & \\
\hline $\begin{array}{c}\text { Mud crab (Scylla } \\
\text { serrata), Snake head } \\
\text { fish (Channa striatus), } \\
\text { Milk fish (Chanos } \\
\text { chanos), Mackerel } \\
\text { (Rastrelliger kanagurta), } \\
\text { Indian anchovy } \\
\text { (Stolephorus indicus), } \\
\text { Indian prawn (Penaeus } \\
\text { indicus), Scampi } \\
\text { (Macrobrachium } \\
\text { rosenbergii), Deep sea } \\
\text { crab Mullet (Mugil } \\
\text { cephalus), Black clam } \\
\text { meat (Villorita } \\
\text { cyprinoides) }\end{array}$ & India & MRSA (8) & t15669, t311 & n.d. & n.d. & [50] \\
\hline
\end{tabular}


Table 2. Cont

\begin{tabular}{|c|c|c|c|c|c|c|}
\hline \multirow{2}{*}{ Animal Species } & \multirow{2}{*}{ Location } & \multirow{2}{*}{$\begin{array}{c}\text { MRSA/MSSA } \\
\text { (Number of } \\
\text { Isolates) }\end{array}$} & \multicolumn{2}{|c|}{ Clonal Lineages } & \multirow{2}{*}{ Virulence } & \multirow{2}{*}{ Reference } \\
\hline & & & spa-Type & ST/CC & & \\
\hline $\begin{array}{c}\text { Mud crab (Scylla } \\
\text { serrata), Pearl spot } \\
\text { (Etroplus suratensis), } \\
\text { Tilapia (Tilapia } \\
\text { mosambica), Mullet } \\
\text { (Mugil cephalus), Indian } \\
\text { anchovy (Stolephorus } \\
\text { indicus), black clam } \\
\text { meat (Villorita } \\
\text { cyprinoides) }\end{array}$ & India & MRSA(6) & $\begin{array}{c}\mathrm{t} 186, \mathrm{t} 121, \mathrm{t} 311 \\
\mathrm{t} 15669\end{array}$ & n.d. & n.d. & {$[50]$} \\
\hline $\begin{array}{c}\text { Shellfish (Corbiculid } \\
\text { heterodont) }\end{array}$ & Nigeria & $\begin{array}{l}\text { MRSA(35) } \\
\text { MSSA(10) }\end{array}$ & n.d. & n.d. & n.d & [51] \\
\hline $\begin{array}{c}\text { Sea Bass } \\
\text { (Dicentrarchus labrax) }\end{array}$ & Korea & MRSA (1) & n.d. & ST72 & PVL- & {$[52]$} \\
\hline Rockfish (Sebastes) & Korea & MRSA (1) & n.d. & ST1 & PVL- & [52] \\
\hline $\begin{array}{c}\text { Short-Finned Pilot } \\
\text { Whales (Globicephala } \\
\text { macrorhynchus) }\end{array}$ & USA & MRSA (6) & t008, t126 & ST8, ST72 & n.d. & [53] \\
\hline $\begin{array}{l}\text { Mute swan, } \\
\text { (Cygnus olor) }\end{array}$ & Sweden & $\operatorname{MSSA}(1)$ & n.d. & CC133 & n.d. & {$[35]$} \\
\hline Moose (Alces alces) & Sweden & MSSA(18) & n.d. & $\begin{array}{l}\text { ST2691 } \\
\text { CC15, } \\
\text { CC } 97\end{array}$ & n.d. & [35] \\
\hline $\begin{array}{l}\text { Harbour porpoise, } \\
\text { (Phocoena phocoena) }\end{array}$ & Sweden & $\operatorname{MSSA}(1)$ & n.d. & CC12 & n.d. & [35] \\
\hline
\end{tabular}

Abbreviations. ST: sequence type; CC: clonal complex; PVL: Panton-Valentine leucocidin; n.d.: not determined. Note: spa-types and CC/ST in bold correspond to MRSA isolates.

A study on the characterization of $S$. aureus in fecal samples of Canadian geese identified the presence of both MSSA and MRSA in these samples. In this study, 182 samples were analyzed. Of these, 13 were contaminated by S. aureus $(7.1 \%, 13 / 182)$. Of the 13 positive S. aureus isolates, seven were MRS's (3.8\%) and six MSSAs (3.3\%). The authors performed the characterization of the isolates using MLST, spa typing and PCR to detect the presence of the Panton-Valentine, mecA and scn protein genes. The results of the molecular characterization showed that a total of eight different spa types were identified among the 13 isolates obtained, of which t008 was the most common $(46.2 \%, 6 / 13)$. A total of five different STs were also identified, ST8 being the most common, followed by ST5. The mecA gene was identified in 53.8\% (7/13) of the isolates, while the scn gene was found in all isolates. As for the PVL gene, only one isolate $(7.7 \%, 1 / 13)$ was considered positive. The isolates also showed resistance to several antibiotics such as penicillin, erythromycin, clindamycin and oxacillin [47]. The presence of $s c n$ and tetracycline susceptibility indicated that the ST398 isolates were likely human-adapted isolates of the CC398 lineages $[54,55]$. In this study it was not clear how the geese acquired S. aureus, or whether it is spread among animals. However, the environmental contamination through freshwater beaches is one possibility. In turn, geese, as well as other birds carrying S. aureus may have spread the bacteria into human areas via their feces [56,57]. Although this is the first study to document MRSA in goose feces, the authors recommend additional research to determine whether animal species including migratory birds are colonized with MRSA or whether they are persistent reservoirs for drug-resistant organisms.

Another study carried out in Italy linked the death of two dolphins to an infection caused by a strain of MRSA. In this study, the two animals of different origins were submitted to a detailed necropsy through microbiological examinations, among others. Confirmation of MRSA was done through genetic analyses such as spa-typing, PFGE and MLST. In both animals, the MRSA strain found belonged to ST8 and spa-type t008. Through the PFGE analysis it was possible to conclude that the analyzed strains were $100 \%$ 
identical. It was also possible to identify the presence of the nuc gene, as well as other genes responsible for antibiotic resistance such as the mecA gene and other penicillinase genes (blaZ, blaI, blaR). This is the first work to identify the ST8 t008 strain in dolphins, although this strain has already been randomly isolated from human patients, as well as from other animals [49]. Previous studies already expressed a concern for the potential pathogenicity of $S$. aureus in those animals [58-61]. However, the authors of this study consider that the predisposing factors impairing the immune system of these dolphins played a central role in their death. Consequently, the isolated bacteria should not be considered as the primary cause of their decease. However, these findings support the need for a continuous monitoring plan to be implemented in both wild animals and domestic animals under human care, both in open and closed water systems.

Hower et al., 2013, identified the presence of MRSA ST8 and ST72 in short-finned pilot whales in a marine mammal rehabilitation center. In this study, in addition to samples from animals, samples from human volunteers, sand and seawater were also analyzed. After characterizing the MSSA and MRSA isolates, the authors concluded that there was a certain degree of similarity between the strains isolated from the environment, whales and volunteers. PGFE analysis indicated that most of the MRSA isolates obtained were identical or highly similar to the human strain USA300 [53]. Because of their natural habitat, it was unlikely that these animals were previously colonized with human-associated strains of MRSA, such as USA300. Nevertheless, studies have reported the presence of MRSA and drug-resistant $S$. aureus in animals with no previous contact with antibiotics, or in animals living in areas with a very low antimicrobial selection pressure [62-64]. The authors suggest that the source of contamination was the beach sand that may have acted as a bacterial reservoir for adjacent waters where the whales were exposed during initial events. Indeed, studies have shown that the water near beaches may be a reservoir of antimicrobial resistant bacteria, including MRSA [65-68]. Thus, this study supports the idea that there is a potential for the transmission of this agent from humans to animals, either directly through contact with them or indirectly through sand or seawater. To prevent or reduce S. aureus spread in these facilities, the authors suggest showering prior to entering the rehabilitation and hand washing. Besides that, protocols to increase flow and filtration of water at rehabilitation sites are also reasonable based on these results.

Colonization by $S$. aureus has also been reported in other aquatic animals such as white swan and common porpoise. One $S$. aureus isolate belonging to the clonal complex CC133 associated with a white swan and an isolate CC112 in a common porpoise has been identified [35].

Other studies of high importance have also revealed the presence of MRSA in marine animals for human consumption. In a study by Rhee and Woo, the authors proposed to determine the susceptibility of $S$. aureus isolates from food samples, as well as to characterize the virulence of MRSA isolates using MLST and PFGE techniques. In this work, 165 strains of $S$. aureus from different origins (meat, fish and processed foods) were analyzed. The 165 isolates obtained exhibited different resistance profiles, with the vast majority $(90.9 \%)$ being resistant to at least one antibiotic. From a general point of view, most of the isolates were resistant to beta-lactams such as penicillin (72.7\%) and ampicillin (72.7\%). The high percentage of resistance to the antibiotics penicillin and ampicillin is, according to the authors, related to the massive administration of these drugs in animal production in Korea. Furthermore, MRSA strains isolated from fish had high minimum inhibition concentrations (MICs) for gentamicin, presumably due to the frequent use of this antibiotic in Korean aquaculture [52]. Of the 165 isolates of S. aureus, four (2.4\%) were identified as MRSA because they were resistant to oxacillin and carried the mecA gene. Of the four strains, one was identified as ST1 and originated from a sea bass sample, two ST72 (meat and rockfish sample) and the remaining sample from a single locus variant of ST72 (ST72 slv) (meat sample). The ST1 strain has already been identified as the largest epidemic clone related to food poisoning incidents in Korea, in addition to being reported as the clone most commonly identified in drug addicts and the homeless, while ST72 is identified as 
the largest CA-MRSA genotype and even caused a community outbreak in the country between 2004 and 2005. These results reinforce the evidence that there is an increasingly large transmission of resistant pathogens, which are a central cause of food poisoning in Korea [52]. Therefore, it is important to improve hygiene in food production practices to limit the spread of antimicrobial-resistant organisms via food $[69,70]$.

In India, a study of the route of MRSA contamination within a fish market revealed the presence of MRSA in several species of fish and shellfish. According to the authors, since S. aureus and MRSA are not native residents of the fish flora, the contamination of these animals must occur through water or through their inadequate handling [50]. Murugadas et al., 2017, collected samples from the locations of the dock to the fish market. In total, 17 samples were collected, and the sampling process was repeated the following week to validate the procedure. After the isolation procedure and molecular confirmation by PCR, it was confirmed that $35.2 \%$ and $23.5 \%$ of the samples (1st and 2 nd week of samplings, respectively) contained MRSA. Through the spa-typing technique, it was possible to identify several spa-types ( $\mathrm{t} 186, \mathrm{t} 121, \mathrm{t} 311$ and $\mathrm{t} 15669)$ and trace the contamination route. According to the authors, the sources of contamination of fish and seafood were the lake water and ice used during the handling and conservation of the fish on the dock, which was later transferred to the fish market, indicating a community risk of MRSA infection associated with livestock activity [50]. Although MRSA prevalence is not at a significant level, it is important to be aware that, in the long run, these MRSA clones may become endemic persistent microbial contaminants in seafood and may pose a risk to the public. The authors suggest a continuous documentation of prevalent MRSA clones in the fisheries sector to control the spread of these organisms.

Othman et al., 2018, and Egege et al., 2020, reported the presence of MRSA and MSSA in shellfish samples with resistance to several antibiotics. The first investigated the occurrence of MRSA in a total of 80 samples of green mussel and cockle [48]. Samples were randomly collected from various fish and seafood markets in Malaysia over a 5-month period. The authors used a combination of two techniques (most probable number (MPN) and multiplex polymerase chain reaction (mPCR)) to identify the occurrence of $S$. aureus and MRSA in these samples. In fact, the occurrence of S. aureus and MRSA in these samples was $15 \%$ and $8.5 \%$, respectively, with a microbial load ranging from $<3$ to $12.2 \mathrm{MPN} / \mathrm{g}$. The authors also tested the susceptibility of the isolates to 17 antibiotics using the disk diffusion method. The results showed that all isolates were resistant to amikacin and penicillin. However, there was no resistance to the remaining antibiotics tested. Furthermore, coagulase-negative Staphylococcus were reported [51].

It is known that the occurrence of S. aureus is linked with high-protein foods, such as seafood. Heating, sanitizing agents, proper handling practices and a higher quality of raw fish could be good measures to prevent the spread of S. aureus and other pathogenic bacteria [71,72]. In these studies of marine animals for human consumption, fish and shellfish are of high importance as these are generally consumed raw or partially cooked, so there is a high risk of transmission to humans.

Although only a few studies have been conducted regarding the presence of MRSA and MSSA in aquatic animals, the most common clonal lineage among these animals was ST8-t008. This particular clone is also known as the USA300 and is one of most widespread S. aureus clones [73]. Initially, this clone was associated with CA-MRSA, but it has been isolated from patients in healthcare facilities, animals and the environment [73-76]. USA300 gained much attention recently due to its pathogenic properties and virulence which were linked to severe infections [77]. MRSA USA300 strains had a few specific features such as belonging to SCCmecIV and being PVL-positive [74]. However, most of the studies mentioned above did not investigate the SCCmec type, nor the presence of PVL. MRSA ST72 was detected in two animals, namely, whales and sea bass, from the USA and Korea, respectively. ST72 was the most significant and prevalent CA-MRSA clone in South Korea [78]. Nevertheless, this clone has been identified in the meat and milk production chain in Korea $[79,80]$. CC133 and CC97 were also detected in aquatic animals. Both clonal 
lineages were associated with ruminants and were reported in [81,82]. Other MRSA and MSSA clonal complexes found among aquatic animals, such as, CC1, CC12 and CC15, were common in human strains, either causing infections or colonizing the organism [83].

\section{Conclusions}

The results obtained in different studies show that $S$. aureus is widely distributed in the aquatic environment, presenting a huge diversity of genetic lineages. Some of these strains have previously been associated with humans and other animals. Strain 398 is the strain that manages to infect a wider spectrum of hosts, having been identified in several different species. Furthermore, many of these strains have virulence factors and antibiotic resistance genes, in part due to the use of these drugs in aquaculture. For this reason, it is increasingly important to distinguish between the different reservoir-adapted clades of MSSA and MRSA to better control the spread paths and to implement more focused measures to prevent MRSA from spreading.

This review, as with some previous studies in this field, highlights that particular attention must be paid to the early recognition of a scenario in which MRSA from animals could readapt to humans and be retransmitted to animals, where it can become a frequent colonizer and transmit once again to humans and have a pronounced capacity to spread.

In future studies, we suggest that DNA sequencing (such as whole-genome sequencing) will be helpful to elucidate the process of MSSA or MRSA re-adaptation and to better understand the type of the transmission.

Author Contributions: Conceptualization, V.S. and P.P.; validation, A.S., L.M., J.E.P., F.A., G.I. and P.P.; investigation, V.S., A.M. and M.P.; writing—original draft preparation, V.S. and A.M.; writingreview and editing, V.S. and A.M.; supervision, J.L.C., G.I. and P.P. All authors have read and agreed to the published version of the manuscript.

Funding: This work is funded by the R\&D Project CAREBIO2: comparative assessment of antimicrobial resistance in environmental biofilms through proteomics-towards innovative theranostic biomarkers, with reference NORTE-01-0145-FEDER-030101 and PTDC/SAU-INF/30101/2017, financed by the European Regional Development Fund (ERDF) through the Northern Regional Operational Program (NORTE 2020) and the Foundation for Science and Technology (FCT). This work is supported by the Associate Laboratory for Green Chemistry-LAQV, which is financed by national funds from FCT/MCTES (UIDB/50006/2020 and UIDP/50006/2020) and the financial support to CITAB (UIDB/04033/2020). Vanessa Silva is grateful to FCT (Fundação para a Ciência e a Tecnologia) for financial support through the PhD grant SFRH/BD/137947/2018.

Conflicts of Interest: The authors declare no conflict of interest.

\section{References}

1. Cassini, A.; Högberg, L.D.; Plachouras, D.; Quattrocchi, A.; Hoxha, A.; Simonsen, G.S.; Colomb-Cotinat, M.; Kretzschmar, M.E.; Devleesschauwer, B.; Cecchini, M.; et al. Attributable deaths and disability-adjusted life-years caused by infections with antibiotic-resistant bacteria in the EU and the European Economic Area in 2015: A population-level modelling analysis. Lancet Infect. Dis. 2019, 19, 56-66. [CrossRef]

2. Ventola, C.L. The antibiotic resistance crisis: Part 1: Causes and threats. Pharm. Ther. 2015, 40, $277-283$.

3. Week, T. The antibiotic alarm. Nature 2013, 495, 141.

4. European Centre for Disease Prevention and Control (ECDC). Antimicrobial Consumption in the EU/EEA Annual Epidemiological Report for 2018: Key Facts; ECDC: Stockholm, Sweden, 2019; pp. 1-24.

5. Silva, V.; Capelo, J.L.; Igrejas, G.; Poeta, P. Molecular epidemiology of Staphylococcus aureus lineages in wild animals in Europe: A review. Antibiotics 2020, 9, 122. [CrossRef] [PubMed]

6. Michael, C.A.; Dominey-Howes, D.; Labbate, M. The antimicrobial resistance crisis: Causes, consequences, and management. Front. Public Health 2014, 2, 1-8. [CrossRef] [PubMed]

7. Luyt, C.E.; Bréchot, N.; Trouillet, J.L.; Chastre, J. Antibiotic stewardship in the intensive care unit. Crit. Care 2014, 18, 480. [CrossRef]

8. Lushniak, B.D. Antibiotic resistance: A public health crisis. Public Health Rep. 2015, 130, 118-120. [CrossRef]

9. Anjum, M.F.; Marco-jimenez, F.; Duncan, D.; Marín, C.; Smith, R.P.; Evans, S.J.; Butaye, P.R. Livestock-associated methicillinresistant Staphylococcus aureus from animals and animal products in the UK. Front. Microbiol. 2019, 10, 2136. [CrossRef] [PubMed] 
10. Argudín, M.A.; Deplano, A.; Meghraoui, A.; Dodémont, M.; Heinrichs, A.; Denis, O.; Nonhoff, C.; Roisin, S. Bacteria from animals as a pool of antimicrobial resistance genes. Antibiotics 2017, 6, 12. [CrossRef] [PubMed]

11. Viswanathan, V.K. Off-label abuse of antibiotics by bacteria. Gut Microbes 2014, 5, 3-4. [CrossRef] [PubMed]

12. Santos, L.; Ramos, F. Antimicrobial resistance in aquaculture: Current knowledge and alternatives to tackle the problem. Int. J. Antimicrob. Agents 2018, 52, 135-143. [CrossRef] [PubMed]

13. Wall, B.A.; Mateus, A.L.P.; Marshall, L.; Pfeiffer, D.U.; Lubroth, J.; Ormel, H.J.; Otto, P.; Patriarchi, A. Drivers, Dynamics and Epidemiology of Antimicrobial Resistance in Animal Production; Food and Agriculture Organization of the United Nations: Rome, Italy, 2016; ISBN 9251094411.

14. Thanner, S.; Drissner, D.; Walsh, F. Antimicrobial resistance in agriculture. MBio 2016, 7, e02227-15. [CrossRef] [PubMed]

15. Fouz, N.; Pangesti, K.N.A.; Yasir, M.; Al-Malki, A.L.; Azhar, E.I.; Hill-Cawthorne, G.A.; Abd El Ghany, M. The contribution of wastewater to the transmission of antimicrobial resistance in the environment: Implications of mass gathering settings. Trop. Med. Infect. Dis. 2020, 5, 33. [CrossRef] [PubMed]

16. Bürgmann, H.; Frigon, D.; Gaze, W.H.; Manaia, C.M.; Pruden, A.; Singer, A.C.; Smets, B.F.; Zhang, T. Water and sanitation: An essential battlefront in the war on antimicrobial resistance. FEMS Microbiol. Ecol. 2018, 94, fiy101. [CrossRef]

17. Savini, V.; Catavitello, C.; Bianco, A.; Balbinot, A.; D'Antonio, D. Epidemiology, pathogenicity and emerging resistances in staphylococcus pasteuri: From mammals and lampreys, to man. Recent Pat. Antiinfect. Drug Discov. 2009, 4, 123-129. [CrossRef]

18. Gillaspy, A.F.; Iandolo, J.J. Defining statement. Encycl. Microbiol. 2009, 3, 478-491.

19. Parlet, C.P.; Brown, M.M.; Horswill, A.R. Commensal staphylococci influence Staphylococcus aureus skin colonization and disease. Trends Microbiol. 2019, 27, 497-507. [CrossRef]

20. Reddy, P.N.; Srirama, K.; Dirisala, V.R. An update on clinical burden, diagnostic tools, and therapeutic options of Staphylococcus aureus. Infect. Dis. Res. Treat. 2017, 10, 1179916117703999.

21. Leung, Y.L. Staphylococcus aureus, 3rd ed.; Elsevier: Amsterdam, The Netherlands, 2014; Volume 4, ISBN 9780123864543.

22. Lee, A.S.; De Lencastre, H.; Garau, J.; Kluytmans, J.; Malhotra-Kumar, S.; Peschel, A.; Harbarth, S. Methicillin-resistant Staphylococcus aureus. Nat. Publ. Gr. 2018, 4, 1-23. [CrossRef]

23. Lakhundi, S.; Zhang, K. Methicillin-resistant Staphylococcus aureus: Molecular characterization, evolution, and epidemiology. Clin. Microbiol. Rev. 2018, 31, e00020-18. [CrossRef]

24. Fuda, C.C.S.; Fisher, J.F.; Mobashery, S. $\beta$-Lactam resistance in Staphylococcus aureus: The adaptive resistance of a plastic genome. Cell. Mol. Life Sci. 2005, 62, 2617-2633. [CrossRef]

25. Urushibara, N.; Aung, M.S.; Kawaguchiya, M.; Kobayashi, N. Novel staphylococcal cassette chromosome mec (SCCmec) type XIV (5A) and a truncated SCCmec element in SCC composite islands carrying speG in ST5 MRSA in Japan. J. Antimicrob. Chemother. 2020, 75, 46-50. [CrossRef]

26. Kateete, D.P.; Bwanga, F.; Seni, J.; Mayanja, R.; Kigozi, E.; Mujuni, B.; Ashaba, F.K.; Baluku, H.; Najjuka, C.F.; Källander, K.; et al. CA-MRSA and HA-MRSA coexist in community and hospital settings in Uganda. Antimicrob. Resist. Infect. Control. $2019,8,94$. [CrossRef]

27. Choo, E.J. Community-associated methicillin-resistant Staphylococcus aureus in nosocomial infections. Infect. Chemother. 2017, 49, 158-159. [CrossRef]

28. Peng, H.; Liu, D.; Ma, Y.; Gao, W. Comparison of community- and healthcare-associated methicillin- resistant Staphylococcus aureus isolates at a Chinese tertiary hospital, 2012-2017. Sci. Rep. 2018, 8, 17916. [CrossRef]

29. Aires-de-Sousa, M. Methicillin-resistant Staphylococcus aureus among animals: Current overview. Clin. Microbiol. Infect. 2017, 23, 373-380. [CrossRef]

30. Voss, A.; Loeffen, F.; Bakker, J.; Klaassen, C.; Wulf, M. Methicillin-resistant Staphylococcus aureus in pig farming. Emerg. Infect. Dis. 2005, 11, 1965-1966. [CrossRef] [PubMed]

31. Analysis of the baseline survey on the prevalence of methicillin-resistant Staphylococcus aureus (MRSA) in holdings with breeding pigs, in the EU, 2008-Part A: MRSA prevalence estimates. EFSA J. 2009, 7, 1376.

32. Silva, V.; Vieira-Pinto, M.; Saraiva, C.; Manageiro, V.; Reis, L.; Ferreira, E.; Caniça, M.; Capelo, J.L.; Igrejas, G.; Poeta, P. Prevalence and characteristics of multidrug-resistant livestock-associated methicillin-resistant Staphylococcus aureus (LA-MRSA) CC398 isolated from quails (Coturnix Coturnix Japonica) slaughtered for human consumption. Animals 2021, 11, 2038. [CrossRef] [PubMed]

33. Hansen, J.E.; Ronco, T.; Stegger, M.; Sieber, R.N.; Fertner, M.E.; Martin, H.L.; Farre, M.; Toft, N.; Larsen, A.R.; Pedersen, K. LA-MRSA CC398 in dairy cattle and veal calf farms indicates spillover from pig production. Front. Microbiol. 2019, 10, 2733. [CrossRef] [PubMed]

34. Cuny, C.; Wieler, L.; Witte, W. Livestock-associated MRSA: The impact on humans. Antibiotics 2015, 4, 521-543. [CrossRef] [PubMed]

35. Monecke, S.; Gavier-Widén, D.; Hotzel, H.; Peters, M.; Guenther, S.; Lazaris, A.; Loncaric, I.; Müller, E.; Reissig, A.; Ruppelt-Lorz, A.; et al. Diversity of Staphylococcus aureus isolates in European wildlife. PLoS ONE 2016, 11, e0168433. [CrossRef] [PubMed]

36. Tenhagen, B.A.; Vossenkuhl, B.; Käsbohrer, A.; Alt, K.; Kraushaar, B.; Guerra, B.; Schroeter, A.; Fetsch, A. Methicillin-resistant Staphylococcus aureus in cattle food chains-Prevalence, diversity, and antimicrobial resistance in Germany. J. Anim. Sci. 2014, 92, 2741-2751. [CrossRef] 
37. Lowder, B.V.; Guinane, C.M.; Zakour, N.L.B.; Weinert, L.A.; Conway-Morris, A.; Cartwright, R.A.; Simpson, A.J.; Rambaut, A.; Nübel, U.; Fitzgerald, J.R. Recent human-to-poultry host jump, adaptation, and pandemic spread of Staphylococcus aureus. Proc. Natl. Acad. Sci. USA 2009, 106, 19545-19550. [CrossRef]

38. Nemati, M.; Hermans, K.; Lipinska, U.; Denis, O.; Deplano, A.; Struelens, M.; Devriese, L.A.; Pasmans, F.; Haesebrouck, F. Antimicrobial resistance of old and recent Staphylococcus aureus isolates from poultry: First detection of livestock-associated methicillin-resistant strain ST398. Antimicrob. Agents Chemother. 2008, 52, 3817-3819. [CrossRef] [PubMed]

39. Wedley, A.L.; Dawson, S.; Maddox, T.W.; Coyne, K.P.; Pinchbeck, G.L.; Clegg, P.; Jamrozy, D.; Fielder, M.D.; Donovan, D.; Nuttall, T.; et al. Carriage of Staphylococcus species in the veterinary visiting dog population in mainland UK: Molecular characterisation of resistance and virulence. Vet. Microbiol. 2014, 170, 81-88. [CrossRef]

40. Coelho, C.; Torres, C.; Radhouani, H.; Pinto, L.; Lozano, C.; Gómez-Sanz, E.; Zaragaza, M.; Igrejas, G.; Poeta, P. Molecular detection and characterization of Methicillin-Resistant Staphylococcus aureus (MRSA) isolates from dogs in Portugal. Microb. Drug Resist. 2011, 17, 333-337. [CrossRef]

41. Cuny, C.; Strommenger, B.; Witte, W.; Stanek, C. Clusters of infections in horses with MRSA ST1, ST254, and ST398 in a veterinary hospital. Microb. Drug Resist. 2008, 14, 307-310. [CrossRef]

42. Porrero, M.C.; Mentaberre, G.; Sánchez, S.; Fernández-Llario, P.; Casas-Díaz, E.; Mateos, A.; Vidal, D.; Lavín, S.; FernándezGarayzábal, J.-F.; Domínguez, L. Carriage of Staphylococcus aureus by free-living wild animals in Spain. Appl. Environ. Microbiol. 2014, 80, 4865-4870. [CrossRef]

43. Sousa, M.; Silva, N.; Borges, V.; Gomes, P.J.; Caniça, M.; Torres, C.; Igrejas, G. MRSA CC398 recovered from wild boar harboring new SCCmec type IV J3 variant. Sci. Total Environ. 2020, 722, 137845. [CrossRef]

44. Silva, V.; Gabriel, S.I.; Borrego, S.B.; Tejedor-Junco, M.T. Antimicrobial resistance and genetic lineages of Staphylococcus aureus from Wild rodents: First report of mecC-positive methicillin-resistant S. aureus (MRSA) in Portugal. Animals 2021, $11,1537$. [CrossRef]

45. Mrochen, D.M.; Schulz, D.; Fischer, S.; Jeske, K.; El Gohary, H.; Reil, D.; Imholt, C.; Trübe, P.; Suchomel, J.; Tricaud, E.; et al. Wild rodents and shrews are natural hosts of Staphylococcus aureus. Int. J. Med. Microbiol. 2018, 308, 590-597. [CrossRef] [PubMed]

46. Heaton, C.J.; Gerbig, G.R.; Sensius, L.D.; Patel, V.; Smith, T.C. Staphylococcus aureus epidemiology in wildlife: A systematic review. Antibiotics 2020, 9, 89. [CrossRef]

47. Thapaliya, D.; Dalman, M.; Kadariya, J.; Little, K.; Mansell, V.; Taha, M.Y.; Grenier, D.; Smith, T.C. Characterization of Staphylococcus aureus in goose feces from State Parks in Northeast Ohio. Ecohealth 2017, 14, 303-309. [CrossRef] [PubMed]

48. Othman, B.R.; Kuan, C.H.; Mohammed, A.S.; Cheah, Y.K.; Tan, C.W.; New, C.Y.; Thung, T.Y.; Chang, W.S.; Loo, Y.Y.; Nakaguchi, Y.; et al. Occurrence of methicillin-resistant Staphylococcus aureus in raw shellfish at retail markets in Malaysia and antibacterial efficacies of black seed (Nigella sativa) oil against MRSA. Food Control 2018, 90, 324-331. [CrossRef]

49. Mazzariol, S.; Corrò, M.; Tonon, E.; Biancani, B.; Centelleghe, C.; Gili, C. Death associated to methicillin resistant Staphylococcus aureus ST8 infection in two dolphins maintained under human care, Italy. Front. Immunol. 2018, 9, 2726. [CrossRef]

50. Murugadas, V.; Joseph, T.C.; Lalitha, K.V. Tracing contamination of methicillin-resistant Staphylococcus aureus (MRSA) into seafood marketing chain by staphylococcal protein A typing. Food Control 2017, 78, 43-47. [CrossRef]

51. Egege, S.R.; Akani, N.P.; Nwankwo, C.E.I. Detection of methicillin-resistant Staphylococcus aureus in ready-to-eat shellfish (Corbiculid heterodont) in Bayelsa State, Nigeria. Microbiol. Res. J. Int. 2020, 30, 22-35. [CrossRef]

52. Rhee, C.H.; Woo, G.J. Emergence and characterization of foodborne methicillin-resistant Staphylococcus aureus in Korea. J. Food Prot. 2010, 73, 2285-2290. [CrossRef]

53. Hower, S.; Phillips, M.C.; Brodsky, M.; Dameron, A.; Tamargo, M.A.; Salazar, N.C.; Jackson, C.R.; Barrett, J.B.; Davidson, M.; Davis, J.; et al. Clonally related methicillin-resistant Staphylococcus aureus isolated from short-finned pilot whales (Globicephala macrorhynchus), human volunteers, and a bayfront cetacean rehabilitation facility. Microb. Ecol. 2013, 65, 1024-1038. [CrossRef]

54. Smith, T.C.; Wardyn, S.E. Human infections with Staphylococcus aureus CC398. Curr. Environ. Health Reports 2015, 2, 41-51. [CrossRef] [PubMed]

55. Bouiller, K.; Bertrand, X.; Hocquet, D.; Chirouze, C. Human infection of methicillin-susceptible Staphylococcus aureus CC398: A Review. Microorganisms 2020, 8, 1737. [CrossRef]

56. Kutkowska, J.; Turska-Szewczuk, A.; Kucharczyk, M.; Kucharczyk, H.; Zalewska, J.; Urbanik-Sypniewska, T. Methicillin-resistant Staphylococcus aureus and glycopeptide-resistant enterococci in fecal samples of birds from South-Eastern Poland. BMC Vet. Res. 2019, 15, 472. [CrossRef] [PubMed]

57. Loncaric, I.; Stalder, G.L.; Mehinagic, K.; Rosengarten, R.; Hoelzl, F.; Knauer, F.; Walzer, C. Comparison of ESBL-And AmpC producing enterobacteriaceae and methicillin-resistant Staphylococcus aureus (MRSA) isolated from migratory and resident population of rooks (Corvus frugilegus) in Austria. PLoS ONE 2014, 8, e84048. [CrossRef]

58. Goertz, C.E.C.; Frasca, S., Jr.; Bohach, G.A.; Cowan, D.F.; Buck, J.D.; French, R.A.; De Guise, S.; Maratea, J.; Hinckley, L.; Ewalt, D. Brucella sp. vertebral osteomyelitis with intercurrent fatal Staphylococcus aureus toxigenic enteritis in a bottlenose dolphin (Tursiops truncatus). J. Vet. Diagn. Investig. 2011, 23, 845-851. [CrossRef]

59. Schaefer, A.M.; Goldstein, J.D.; Reif, J.S.; Fair, P.A.; Bossart, G.D. Antibiotic-resistant organisms cultured from Atlantic bottlenose dolphins (Tursiops truncatus) inhabiting estuarine waters of Charleston, SC and Indian River Lagoon, FL. Ecohealth 2009, 6, 33-41. [CrossRef] [PubMed] 
60. Morris, P.J.; Johnson, W.R.; Pisani, J.; Bossart, G.D.; Adams, J.; Reif, J.S.; Fair, P.A. Isolation of culturable microorganisms from free-ranging bottlenose dolphins (Tursiops truncatus) from the southeastern United States. Vet. Microbiol. 2011, 148, $440-447$. [CrossRef]

61. Stewart, J.R.; Townsend, F.I.; Lane, S.M.; Dyar, E.; Hohn, A.A.; Rowles, T.K.; Staggs, L.A.; Wells, R.S.; Balmer, B.C.; Schwacke, L.H. Survey of antibiotic-resistant bacteria isolated from bottlenose dolphins Tursiops truncatus in the southeastern USA. Dis. Aquat. Organ. 2014, 108, 91-102. [CrossRef]

62. Silva, V.; Pereira, J.E.; Maltez, L.; Ferreira, E.; Manageiro, V.; Caniça, M.; Capelo, J.L.; Igrejas, G.; Poeta, P. Diversity of methicillinresistant staphylococci among wild Lepus granatensis: First detection of mecA-MRSA in hares. FEMS Microbiol. Ecol. 2020, 96, fiz204. [CrossRef]

63. De Mesquita Souza Saraiva, M.; de Leon, C.M.C.G.; da Silva, N.M.V.; Raso, T.F.; Serafini, P.P.; Givisiez, P.E.N.; Gebreyes, W.A.; de Oliveira, C.J.B. Staphylococcus sciuri as a reservoir of mecA to Staphylococcus aureus in non-migratory seabirds from a remote oceanic island. Microb. Drug Resist. 2020, 27, 553-561. [CrossRef]

64. Schaumburg, F.; Pauly, M.; Anoh, E.; Mossoun, A.; Wiersma, L.; Schubert, G.; Flammen, A.; Alabi, A.S.; Muyembe-Tamfum, J.-J.; Grobusch, M.P.; et al. Staphylococcus aureus complex from animals and humans in three remote African regions. Clin. Microbiol. Infect. 2015, 21, 345.e1-345.e8. [CrossRef]

65. Thapaliya, D.; Hellwig, E.J.; Kadariya, J.; Grenier, D.; Jefferson, A.J.; Dalman, M.; Kennedy, K.; DiPerna, M.; Orihill, A.; Taha, M.; et al. Prevalence and characterization of Staphylococcus aureus and methicillin-resistant Staphylococcus aureus on public recreational beaches in Northeast Ohio. GeoHealth 2017, 1, 320-332. [CrossRef]

66. Levin-Edens, E.; Soge, O.O.; No, D.; Stiffarm, A.; Meschke, J.S.; Roberts, M.C. Methicillin-resistant Staphylococcus aureus from Northwest marine and freshwater recreational beaches. FEMS Microbiol. Ecol. 2012, 79, 412-420. [CrossRef] [PubMed]

67. Plano, L.R.W.; Shibata, T.; Garza, A.C.; Kish, J.; Fleisher, J.M.; Sinigalliano, C.D.; Gidley, M.L.; Withum, K.; Elmir, S.M.; Hower, S.; et al. Human-associated methicillin-resistant Staphylococcus aureus from a subtropical recreational marine beach. Microb. Ecol. 2013, 65, 1039-1051. [CrossRef] [PubMed]

68. Akanbi, O.E.; Njom, H.A.; Fri, J.; Otigbu, A.C.; Clarke, A.M. Antimicrobial susceptibility of Staphylococcus aureus isolated from recreational waters and beach sand in Eastern Cape Province of South Africa. Int. J. Environ. Res. Public Health 2017, $14,1001$. [CrossRef] [PubMed]

69. Verraes, C.; Van Boxstael, S.; Van Meervenne, E.; Van Coillie, E.; Butaye, P.; Catry, B.; De Schaetzen, M.-A.; Van Huffel, X.; Imberechts, H.; Dierick, K. Antimicrobial resistance in the food chain: A review. Int. J. Environ. Res. Public Health 2013, 10, 2643-2669. [CrossRef] [PubMed]

70. Jansen, W.; Mueller, A.; Grabowski, N.T.; Kehrenberg, C.; Muylkens, B.; Al Dahouk, S. Foodborne diseases do not respect borders: Zoonotic pathogens and antimicrobial resistant bacteria in food products of animal origin illegally imported into the European Union. Vet. J. 2019, 244, 75-82. [CrossRef]

71. Ganowiak, Z.M. Sanitation in marine food industry. In Seafood: Resources, Nutritional Composition, and Preservation; CRC Press: Boca Raton, FL, USA, 2020; pp. 211-230. ISBN 1003068413.

72. Remya, S.; Mohan, C.O.; Jha, A.K.; Joseph, T.C. Hygiene and Safety of Fish and Fishery Products; ICAR CIFT: Kochi, India, 2018.

73. Varga, M.; Kuntová, L.; Pantůček, R.; Mašlaňová, I.; Růžičková, V.; Doškař, J. Efficient transfer of antibiotic resistance plasmids by transduction within methicillin-resistant Staphylococcus aureus USA300 clone. FEMS Microbiol. Lett. 2012, 332, 146-152. [CrossRef]

74. Mama, O.M.; Gómez-Sanz, E.; Ruiz-Ripa, L.; Gómez, P.; Torres, C. Diversity of staphylococcal species in food producing animals in Spain, with detection of PVL-positive MRSA ST8 (USA300). Vet. Microbiol. 2019, 233, 5-10. [CrossRef]

75. Lepuschitz, S.; Mach, R.; Springer, B.; Allerberger, F.; Ruppitsch, W. Draft genome sequence of a community-acquired methicillinresistant Staphylococcus aureus USA300 isolate from a river sample. Genome Announc. 2017, 5, e01166-17. [CrossRef]

76. Silva, V.; Hermenegildo, S.; Ferreira, C.; Manaia, C.M.; Capita, R.; Alonso-Calleja, C.; Carvalho, I.; Pereira, J.E.; Maltez, L.; Capelo, J.L. Genetic characterization of methicillin-resistant Staphylococcus aureus isolates from human bloodstream infections: Detection of MLSB resistance. Antibiotics 2020, 9, 375. [CrossRef]

77. Klein, S.; Boutin, S.; Heeg, K.; Zanger, P.; Nurjadi, D. Genomic structure of ST8-t008 USA300 and USA300-LV MRSA in the Rhine-Neckar Region, Germany, 2012-2018. Int. J. Antimicrob. Agents 2021, 57, 106312. [CrossRef] [PubMed]

78. Kang, K.-M.; Park, J.-H.; Kim, S.H.; Yang, S.-J. Potential role of host defense antimicrobial peptide resistance in increased virulence of health care-associated MRSA strains of sequence type (ST) 5 versus livestock-associated and community-associated MRSA strains of ST72. Comp. Immunol. Microbiol. Infect. Dis. 2019, 62, 13-18. [CrossRef] [PubMed]

79. Lim, S.-K.; Nam, H.-M.; Jang, G.-C.; Lee, H.-S.; Jung, S.-C.; Kim, T.-S. Transmission and persistence of methicillin-resistant Staphylococcus aureus in milk, environment, and workers in dairy cattle farms. Foodborne Pathog. Dis. 2013, 10, 731-736. [CrossRef]

80. Kim, Y.J.; Oh, D.H.; Song, B.R.; Heo, E.J.; Lim, J.S.; Moon, J.S.; Park, H.J.; Wee, S.H.; Sung, K. Molecular characterization, antibiotic resistance, and virulence factors of methicillin-resistant Staphylococcus aureus strains isolated from imported and domestic meat in Korea. Foodborne Pathog. Dis. 2015, 12, 390-398. [CrossRef] [PubMed]

81. Conceição, T.; de Lencastre, H.; Aires-de-Sousa, M. Healthy bovines as reservoirs of major pathogenic lineages of Staphylococcus aureus in Portugal. Microb. Drug Resist. 2017, 23, 845-851. [CrossRef] 
82. Gharsa, H.; Ben Sallem, R.; Ben Slama, K.; Gómez-Sanz, E.; Lozano, C.; Jouini, A.; Klibi, N.; Zarazaga, M.; Boudabous, A.; Torres, C. High diversity of genetic lineages and virulence genes in nasal Staphylococcus aureus isolates from donkeys destined to food consumption in Tunisia with predominance of the ruminant associated CC133 lineage. BMC Vet. Res. 2012, 8, 203. [CrossRef] [PubMed]

83. Haag, A.F.; Fitzgerald, J.R.; Penadés, J.R. Staphylococcus aureus in animals. Microbiol. Spectr. 2019, 7, 731-746. [CrossRef] [PubMed] 